\title{
Micronutrient and Antinutritional Content of Weaning Food Produced from Blends of Millet, Soya Beans and Moringa Oleifera Leaf Flour
}

\author{
Jane Hembadoon Gwer, Bibiana Dooshima Igbabul and Simon Terver Ubwa
}

\begin{abstract}
Any Weaning food offered to infants should be rich in micronutrients and high in protein quality. The study assessed the Mineral, Vitamin $A$ and $C$, Amino acids and Antinutritional profile of weaning food blends from millet flour (MLF), soya beans flour (SBF) and moringa oleifera leaf flour (MLF) in the ratio FMF:SBF:MLF- sample C (60:35:5), sample D (60:30:10), sample E (60:25:5), sample F (60:20:20) sample A (100 \% FMF) was used as control, sample B (FMF (60):SBF(40). All analyses were done using standard methods. The Mineral, Vitamin A, C and Amino acid Tryptophan contents of the weaning food formulations significantly $(p<0.05)$ increased with increased MLF Percentage. The Mineral values ranged from 57.37 to $466.87 \mathrm{mg} / 100 \mathrm{~g}, 11.33$ to $107.30 \mathrm{mg} / 100 \mathrm{~g}, 36.27$ to 62.38 $\mathrm{mg} / 100 \mathrm{~g}, 2.45$ to $4.77 \mathrm{mg} / 100 \mathrm{~g}$ and 76.64 to $178.09 \mathrm{mg} / 100 \mathrm{~g}$ for calcium, iron, potassium, zinc and sodium respectively. Vitamins A (B-Carotene) and $\mathrm{C}$ ranged from 0-5.25 and 0.58$3.89 \mathrm{mg} / 100 \mathrm{~g}$ respectively. Tryptophan ranged from 1.16-2.40 $\mathrm{g} / 100 \mathrm{~g}$ protein. Manganese, Lysine, methionine was significantly $(p<0.05)$ higher in MLF unsubstituted sample B. The antinutrients analyzed were significantly $(p<0.05)$ low with values ranging from $(0.09$ to 0.43$) \mathrm{mg} / 100 \mathrm{~g},(0.13$ to 1.49$) \mathrm{mg} / 100 \mathrm{~g}$, $(0.33$ to 0.95$) \mathrm{mg} / 100 \mathrm{~g}$ and $(0.03$ to 0.07$) \mathrm{mg} / 100 \mathrm{~g}$ for phytates, tannins, oxalates and trypsin inhibitor respectively.
\end{abstract}

Index Terms - Amino acids, Antinutrients, Micronutrients, Weaning Food.

\section{INTRODUCTION}

In Africa, children are usually weaned with porridges made from either of the cereals such as maize, millet, sorghum or wheat. Cereals are the major dietary energy suppliers and provide significant amount of fat, protein, minerals (potassium and calcium) and B vitamins [1]. The cereal grains such as millet, provide more than $70 \%$ of calories for the majority of poor people in the developing world [2]. Cereal products are limiting in some essential amino acids which make them to have poor nutritional value [3]. Considering that porridges made from cereals are the primary weaning foods in West Africa, efforts has been made by several researchers in enriching the porridges with legumes which supply the protein lacking in cereals [4]. Millet protein is deficient in lysine and tryptophan but has fair amounts of sulphur-containing amino acids (methionine and cystine) [5]. Soya bean is an excellent raw material to improve the nutritional quality of millet-based products especially protein quality, because of its complete amino acids profile [6]. It is

Published on October 17, 2020

Jane Hembadoon Gwer, Benue State University Makurdi, Nigeria. (e-mail: janegwer86@ gmail.com)

Bibiana Dooshima Igbabul, Federal University of Agriculture Makurdi, Nigeria.

(e-mail: bibibu146@gmail.com) however evident that cereals-legumes blend is low in micronutrients. Various sources of micronutrients have been proposed and utilized with the aim of fortifying weaning foods. However, a continuous search for a relatively cost effective and readily available plant has led to the discovery of Moringa plant. Moringa (Moringa oleifera) often referred to as miracle tree could be a solution to the making of a complete weaning food. This is because every part of it can be used for food, medication and industrial purposes [7]. Especially, the leaves of the tree is a potential source to improve micronutrients, boost food security and foster rural development. The tree could be a solution to the problem of weaning food in developing countries. Studies have shown that the leaves have immense nutritional values such as minerals, vitamins and amino acids and as a result, the leaves have been used to combat malnutrition especially among infants and nursing mothers [8], [9]. The substitution of millet and soya bean weaning food formulations with Moringa oleifera leaf flour can dramatically improve their protein and micronutrient quality [10]

\section{MATERIALS AND METHODS}

\section{A. Study Area}

The study area was Makurdi Metropolis of Benue State located within Latitude $7.7322^{\circ} \mathrm{N}$ and Longitude $8.5391^{\circ} \mathrm{E}$ with an estimated area of $41,035 \mathrm{Km}^{2}$ and has a population put at 342500 [11].

\section{B. Sample Collection}

Millets and Soya beans were purchased from Wurukum market, Makurdi in Benue state, while fresh Moringa oleifera leaves were obtained from moringa oleifera plants in the College of Food Technology, University of Agriculture, Makurdi.

\section{SAMPLE PREPARATION}

\section{A. Preparation of fermented millet flour}

Fermented millet flour was prepared using a modified method of Enujiugha [12]. High quality millet was carefully selected and sorted, then washed to remove dust and stones. The grains were then soaked for $24 \mathrm{~h}$ at ambient temperature of $28 \pm 3{ }^{\circ} \mathrm{C}$ and Relative humidity of $65 \pm 3 \%$, rinsed to get rid

Simon Terver Ubwa, Benue State University Makurdi, Nigeria. (e-mail: drsimonterverubwa ${ }^{\circledR}$ gmail.com) 
of the soaked water, wet milled using an attrition mill (Senwei GX160) and sieved with muslin cloth. The resultant slurry was fermented for $24 \mathrm{~h}$ at $30 \pm 1{ }^{\circ} \mathrm{C}$ after which it was dewatered, then tied in a sack cloth and suspended to drain most of the free water for $12 \mathrm{~h}$ and then dried for $5 \mathrm{~h}$ at $60{ }^{\circ} \mathrm{C}$ in an oven (Genlab oven model ov/100/F). The dried fermented flour lumps were broken down and milled into finer flour particles using a hammer mill and passed through $0.25 \mathrm{~mm}$ sieve to achieve fine fermented millet flour.

\section{B. Preparation of soya beans flour}

Soya beans flour was prepared using the method described by Solomon [13]. The Soya beans were washed and soaked in distilled water for $8 \mathrm{~h}$, at ambient temperature of $28 \pm 3{ }^{\circ} \mathrm{C}$. The soaked soya beans were cooked in boiling water for 20 minutes, then dehulled by washing and rubbing between the palms to remove testa, then washed again several times with more distilled water to remove the hulls, then drained on a flat sieve for $1 \mathrm{~h}$. The boiled and dehulled beans were dried for $5 \mathrm{~h}$ at $60{ }^{\circ} \mathrm{C}$, then roasted at $200{ }^{\circ} \mathrm{C}$ for 30 minutes in the oven (Genlab oven model ov/100/F). The roasted beans were allowed to cool and milled into flour (using a hammer mill), the flour was then passed through $0.25 \mathrm{~mm}$ sieve to achieve fine soya beans flour.

\section{Preparation of Moringa oleifera leaf flour}

Moringa oleifera leaf flour was prepared using a modified method of Shiriki et al. [14]. Moringa oleifera leaves were washed in clean tap water containing $5 \%$ Sodium chloride. They were then drained, spread thinly on trays and dried indoors at room temperature $\left(28 \pm 3{ }^{\circ} \mathrm{C}\right)$ for 24 hours, transferred to the oven (Genlab oven model ov/100/F) and dried at $40{ }^{\circ} \mathrm{C}$ for $1 \mathrm{~h}$, then milled into flour using Kenwood electric blender BL 440 and sieved with a fine sieve $(0.25$ $\mathrm{mm}$ ) to achieve moringa oleifera leaf flour.

\section{PRODUCT ForMULATION}

The treated flour samples of millets, soya beans and moringa oleifera leaves were formulated into six different weaning food samples. Exactly $100 \%$ fermented millet flour (sample A) was used as the control. Fermented millet flour and soya beans flour were blended in the ratio 60:40 (sample B). Fermented millet flour, soya beans flour and moringa oleifera leaf flour were blended in the ratio 60:35:5 (sample C), 60:30:10 (sample D), 60:25:15 (sample E) and 60:20:20 (sample F). The proportions at different levels were mixed in a Kenwood mixer to achieve a uniform blending to produce the weaning food samples. They were carefully packaged and sealed in polythene bags and kept tightly covered in glass jars for further analysis.

\section{ANALYSIS}

Mineral content of the food formulations was determined using Atomic Absorption Spectrophotomer (AAS model UNICAM 969 Solar) as described by AOAC [15]. Vitamin A was determined by the adaptation of the method described by Alexander and Griffiths [16] where the value of ß-carotene obtained was divided by 6 to get a rough estimate of Vitamin A); Vitamin C (Ascorbic acid) content was determined by titrimetric method [17]. Quantitative determination of amino acids was carried out using the method described by Kaspar et al. [18] and Tryptophan was determined using the method described by Margit and Ibolya [19]. Anti - nutritional factors (Phytates, Oxalates and Tanins) were determined using the Isocratic High Performance Liquid Chromatography (HPLC) as described by Onwuka [20], and Trypsin inhibitors [21].

\section{STATISTICAL ANALYSIS}

The data generated were statistically analyzed for means and standard deviation and Analysis of Variance (ANOVA) was used to test the level of significance. Duncan's New Multiple Range Test was used to compare and separate means. Significance was accepted at $(p<0.05)$. The charts were plotted using Microsoft Excel 2013 version.

\section{RESULTS}

\section{A. Mineral}

The result of the mineral content of the weaning food samples is presented in the order A, B, C D, E and F. Calcium $(\mathrm{Ca})$, Iron $(\mathrm{Fe})$, Potassium $(\mathrm{K})$, Zinc (Zn), Sodium (Na), Magnesium $(\mathrm{Mg})$ and Maganese $(\mathrm{Mn})$.

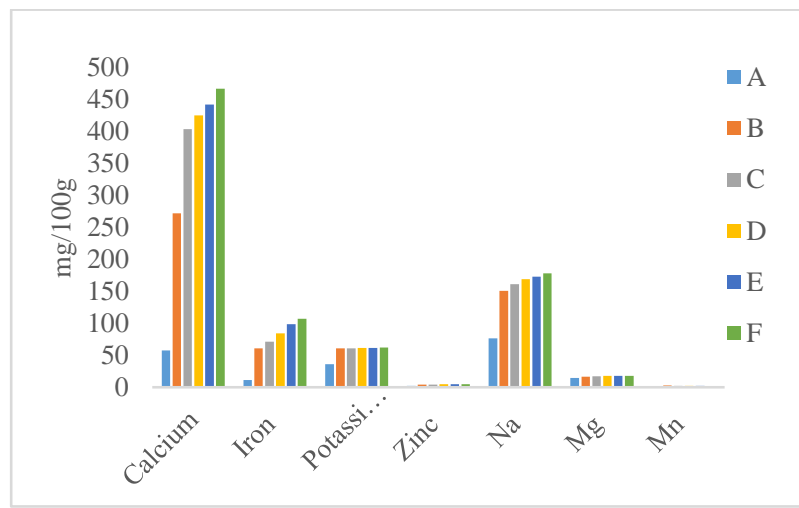

Fig. 1. Mineral composition of the formulated weaning food blends from millet soya beans and moringa oleifera leaf flour.

$\mathrm{A}=100 \%$ Fermented millet flour (The Control);

$\mathrm{B}=60 \%$ Fermented millet and $40 \%$ Soya beans flour;

$\mathrm{C}=60 \%$ Fermented millet and 35\% Soya beans and 5\% Moringa oleifera leaf flour;

$\mathrm{D}=60 \%$ Fermented millet and $30 \%$ Soya beans and $10 \%$ Moringa oleifera leaf flour;

$\mathrm{E}=60 \%$ Fermented millet and $25 \%$ Soya beans and $15 \%$ Moringa oleifera leaf flour;

$\mathrm{F}=60 \%$ Fermented millet and $20 \%$ Soya beans and $20 \%$ Moringa oleifera leaf flour.

Ca content of the MLF substituted samples increased significantly $(\mathrm{p}<0.05)$ with increased MLF Percentage. Values obtained were $(57.37 \pm 2.40, \quad 271.70 \pm 2.35$, $403.37 \pm 3.01, \quad 425.27 \pm 2.58, \quad 441.87 \pm 1.74 \quad$ and $466.87 \pm 3.25) \mathrm{mg} / 100 \mathrm{~g}$. Iron (Fe) values obtained were $(11.33 \pm 0.20, \quad 60.83 \pm 0.45, \quad 71.40 \pm 1.08, \quad 84.60 \pm 0.30$, $98.93 \pm 0.35$ and $107.30 \pm 0.46) \mathrm{mg} / 100 \mathrm{~g}$. The potassium values obtained were $(360.27 \pm 0.04,600.63 \pm 0.01$, $610.04 \pm 0.01,617.56 \pm 0.01,629.62 \pm 0.02$ and $641.38 \pm 0.01)$ $\mathrm{mg} / 100 \mathrm{~g}$. $\mathrm{Zn}$ values were $(2.45 \pm 0.01,4.18 \pm 0.01,4.29 \pm 0.01$, $4.54 \pm 0.01,4.57 \pm 0.01$ to $4.77 \pm 0.01) \mathrm{mg} / 100 \mathrm{~g}$. Sodium values were $(76.64 \pm 0.01,150.97 \pm 0.01,161.08 \pm 0.01,169.01 \pm 0.01$, $172.79 \pm 0.01$ and $178.09 \pm 0.00) \mathrm{mg} / 100 \mathrm{~g}$. Magnesium values 
were $(14.28 \pm 0.01,16.76 \pm 0.01,17.26 \pm 0.01,17.52 \pm 0.01$, $17.67 \pm 0.02$ and $17.79 \pm 0.01) \mathrm{mg} / 100 \mathrm{~g}$ with the control having the lowest and sample $\mathrm{F}$ with the highest.

The Mangenese $(\mathrm{Mn})$ values were $(0.58 \pm 0.01,2.53 \pm 0.01$ $2.16 \pm 0.01,2.08 \pm 0.01,1.95 \pm 0.01$ and $1.83 \pm 0.01) \mathrm{mg} / 100 \mathrm{~g}$ for samples A, B, C, D, E and F respectively. The Mn content was observed to be highest in sample B, lowest in sample A, and decreased significantly $(\mathrm{p}<0.05)$ in MLF substituted samples with increased MLF percentage.

\section{B. Vitamin $A$ and $C$}

The result of Vitamin A (Beta Carotene) and Vitamin C content of the weaning food formulation from millet, soya beans and moringa oleifera flour is shown in Table I. Moringa oleifera flour substitution significantly $(\mathrm{p}<0.05)$ increased the Beta carotene and Vitamins $\mathrm{C}$ content of the formulated weaning food with increased MLF percentage, with values in the range 0.00 to $5.25 \mathrm{mg} / 100 \mathrm{~g}$ and 0.58 to $3.89 \mathrm{mg} / 100 \mathrm{~g}$ respectively.

TABLE I: BETA CAROTENE AND VITAMIN C CONTENT OF THE FORMULATED WEANING FOOD BLENDS

\begin{tabular}{ccc}
\hline Sample & $\begin{array}{c}\text { Beta carotene } \\
(\mathrm{mg} / 100 \mathrm{~g})\end{array}$ & $\begin{array}{c}\text { Vitamin C } \\
(\mathrm{mg} / 100 \mathrm{~g})\end{array}$ \\
\hline A & $0.00^{\mathrm{f}} \pm 0.00$ & $0.58^{\mathrm{f}} \pm 0.02$ \\
B & $1.68^{\mathrm{e}} \pm 0.06$ & $0.77^{\mathrm{e}} \pm 0.03$ \\
C & $2.91^{\mathrm{d}} \pm 0.04$ & $2.10^{\mathrm{d}} \pm 0.15$ \\
D & $3.83^{\mathrm{c}} \pm 0.03$ & $2.84^{\mathrm{c}} \pm 0.04$ \\
E & $4.43^{\mathrm{b}} \pm 0.03$ & $3.31^{\mathrm{b}} \pm 0.04$ \\
F & $5.25^{\mathrm{a}} \pm 0.02$ & $3.89^{\mathrm{a}} \pm 0.02$ \\
\hline
\end{tabular}

Values are means \pm SD of triplicate determinations. Means within the same column bearing different superscript are significantly different $(\mathrm{p}<0.05)$

\section{Amino Acids}

Figure 2 shows the result of essential amino acids profile of the formulated weaning food samples. The essential amino acid Tryptophan increased significantly $(p<0.05)$ in MLF substituted samples with increased MLF percentage, with values ranging from 1.16 to $2.40 \mathrm{~g} / 100 \mathrm{~g}$ protein. Methionine, lysine threonine, isoleucine, leucine and histidine were observed to be lowest in the control, highest in sample B and decreased significantly $(\mathrm{p}<0.05)$ with increased MLF percentage, with values ranging from (2.01 to $3.06,3.05$ to $4.96,2.88$ to $3.94,3.24$ to 4.44 and 0.28 to 2.68$) \mathrm{g} / 100 \mathrm{~g}$ protein respectively. Phenylalanine and valine decreased significantly $(\mathrm{p}<0.05)$ with increased MLF percentage with values ranging from (2.08 to3.51 and 3.15 to 4.85$) \mathrm{g} / 100 \mathrm{~g}$ protein respectively.

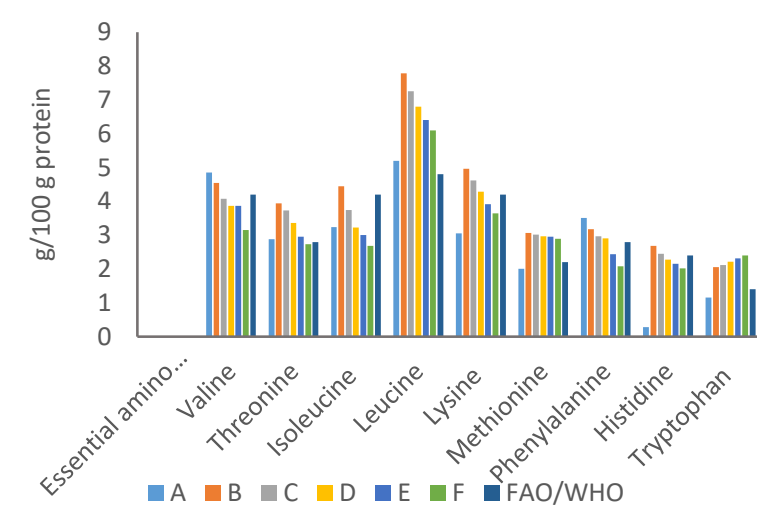

Fig. 2. Essential amino acids of the formulated weaning food from millet, soya beans and moringa oleifera leaf flour.

\section{Anti-Nutrients}

The anti-nutrients analyzed were significantly $(\mathrm{p}<0.05)$ low with values ranging from $(0.09$ to 0.43$) \mathrm{mg} / 100 \mathrm{~g},(0.13$ to 1.49$) \mathrm{mg} / 100 \mathrm{~g}$, (0.33 to 0.95$) \mathrm{mg} / 100 \mathrm{~g}$ and $(0.03$ to $0.07) \mathrm{mg} / 100 \mathrm{~g}$ for phytates, tannins, oxalates and trypsin inhibitor respectively. However, phytates was highest in sample A and decreased significantly $(\mathrm{p}<0.05)$ with increased MLF percentage. Tannin and Trypin inhibitor were highest in sample B and decreased significantly $(\mathrm{p}<0.05)$ with increased MLF percentage, while oxalate increased significantly $(p<0.05)$ with increased MLF percentage.

TABLE II: ANTINUTRIENT PROPERTIES OF THE FoRMULATED WEANING FOOD BLENDS

\begin{tabular}{ccccc} 
Samples & $\begin{array}{c}\text { Phytates } \\
(\mathrm{mg} / 100 \mathrm{~g})\end{array}$ & $\begin{array}{c}\text { Tannins } \\
(\mathrm{mg} / 100 \mathrm{~g})\end{array}$ & $\begin{array}{c}\text { Oxalate } \\
(\mathrm{mg} / 100 \mathrm{~g})\end{array}$ & $\begin{array}{c}\text { Trypsin } \\
\text { inhibitor } \\
(\mathrm{mg} / 100 \mathrm{~g})\end{array}$ \\
\hline $\mathbf{A}$ & $0.21^{\mathrm{cd}} \pm 0.02$ & $0.13^{\mathrm{f}} \pm 0.02$ & $0.33^{\mathrm{f}} \pm 0.03$ & $0.03^{\mathrm{e}} \pm 0.02$ \\
$\mathbf{B}$ & $0.43^{\mathrm{a}} \pm 0.02$ & $1.49^{\mathrm{a}} \pm 0.01$ & $0.58^{\mathrm{e}} \pm 0.04$ & $0.07^{\mathrm{a}} \pm 0.04$ \\
$\mathbf{C}$ & $0.32^{\mathrm{b}} \pm 0.02$ & $1.12^{\mathrm{b}} \pm 0.01$ & $0.66^{\mathrm{d}} \pm 0.03$ & $0.07^{\mathrm{a}} \pm 0.01$ \\
$\mathbf{D}$ & $0.27^{\mathrm{bc}} \pm 0.04$ & $0.86^{\mathrm{c}} \pm 0.01$ & $0.76^{\mathrm{c}} \pm 0.04$ & $0.06^{\mathrm{b}} \pm 0.02$ \\
$\mathbf{E}$ & $0.17^{\mathrm{d}} \pm 0.02$ & $0.72^{\mathrm{d}} \pm 0.02$ & $0.85^{\mathrm{b}} \pm 0.04$ & $0.05^{\mathrm{c}} \pm 0.03$ \\
$\mathbf{F}$ & $0.09^{\mathrm{e}} \pm 0.01$ & $0.55^{\mathrm{c}} \pm 0.01$ & $0.95^{\mathrm{a}} \pm 0.03$ & $0.04^{\mathrm{d}} \pm 0.01$ \\
\hline
\end{tabular}

Values are means \pm SD of triplicate determinations. Means within the same column bearing different superscript are significantly different $(p<0.05)$.

\section{DISCUSSION}

\section{A. Mineral}

The mineral content of the Moringa oleifera leaf (MLF) substituted samples contained substantial amounts of $\mathrm{Ca}$, $\mathrm{Fe}, \mathrm{K}, \mathrm{Zn}, \mathrm{Mg}$ and significantly $(\mathrm{p}<0.05)$ increased with increased MLF percentage. The observed increase in $\mathrm{Ca}, \mathrm{Fe}$, $\mathrm{K}, \mathrm{Zn}, \mathrm{Mg}$ contents of the weaning food formulations is in accordance with the work of Shiriki et al. [22]. Abioye and Aka [23] also reported an increased mineral content when Maize-ogi was supplemented with moringa oleifera leaf flour.

The Ca content in this study which was in the range 403.37 to $466.87 \mathrm{mg} / 100 \mathrm{~g}$ compares favourably with the Recommended Dietary Allowance (RDA) of $400 \mathrm{mg}$ for children between 0-3 years [24]. MLF at $5 \%$ in the formulation is enough to meet up with the RDA [24]. Calcium is an essential micronutrient in infants and young children for building bones and teeth, functioning of muscles and nerves, blood clotting and for immune defense [25].

The Iron $(\mathrm{Fe})$ content in the range 11.33 to $107.30 \mathrm{mg} / 100 \mathrm{~g}$ significantly $(\mathrm{p}<0.05)$ increased with increased MLF percentage. The control sample compared favourably with the RDA, but MLF substituted samples were significantly $(\mathrm{p}<0.05)$ higher than the RDA for infants 7 to 12 months which is $11 \mathrm{mg}$ [24]. It must be noted that iron provided by the formulated weaning food in this study is nonheme which is less bioavailable for human absorption unlike the iron from animal which is more bioavailable [26]. Iron in weaning foods is needed for the production of hemoglobin which carries oxygen in the blood [27].

Zinc (Zn) content was in the range 2.45 to $4.77 \mathrm{mg} / 100 \mathrm{~g}$. The $\mathrm{Zn}$ content of the MLF substituted samples were significantly $(\mathrm{p}<0.05)$ higher than the RDA for infants $0-1$ year which is $3.9 \mathrm{mg} / \mathrm{day}$ [24]. The $\mathrm{Zn}$ content observed to 
have increased upon substitution with MLF maybe as a result of high $\mathrm{Zn}$ content in Moringa oleifera leaves. Adding moringa oleifera leaf flour to cereal-legume blends has also been shown to improve the $\mathrm{Zn}$ and $\mathrm{Fe}$ content of weaning foods [28]. $\mathrm{Zn}$ is involved in cellular growth and differentiation. $\mathrm{Zn}$ has been shown to be an essential component or cofactor in the enzyme that converts provitamin A into retinol and its deficiency seems to interfere with Vitamin A metabolism [29].

Potassium (K) content of the formulated weaning food which was in the range 360.27 to $641.27 \mathrm{mg} / 100 \mathrm{~g}$ is significantly $(\mathrm{p}<0.05)$ lower than the RDA of $800 \mathrm{mg} / \mathrm{day}$ for children 1 to 3 years [24]. MLF at 20\% in the formulations will provide up to $80 \%$ of the RDA. The significant increase of $\mathrm{K}$ in MLF substituted samples maybe due to the high content of $\mathrm{K}$ content in soya beans and moringa oleifera leaves [30]. A major function of potassium is helping the body to maintain normal water balance in cells, transmit nerve impulses, keep acids and alkalis in balance and stimulate normal movement of the intestinal tract [31].

Magnesium $(\mathrm{Mg})$ values obtained in this study in the range 14.28 to $17.67 \mathrm{mg} / 100 \mathrm{~g}$ is significantly $(\mathrm{p}<0.05)$ lower than the recommended daily intake (RDI) of $75 \mathrm{mg}$ /day for infants 7-12 months [32]. Netshiheni [33] who worked on maize porridge fortified with Moringa oleifera leaves and termite reported values higher than the recommended daily intake. This disparity in the findings may be due to the fact that Moringa oleifera leaves have been reported to differ in nutrient composition at different locations [34].

The Sodium $(\mathrm{Na})$ content in the range 76.64 to 178.09 $\mathrm{mg} / 100 \mathrm{~g}$ is significantly $(\mathrm{p}<0.05)$ lower than the RDI of 200 $\mathrm{mg} /$ day for infants 7-12 months [35]. MLF at $20 \%$ substitution in the formulation will provide $89 \%$ of the RDI value.

\section{B. Vitamin $A$ and $C$}

Vitamin A (Beta Carotene) was in the range 0.00 to $5.25 \mathrm{mg} / 100 \mathrm{~g}$. The absence of Beta carotene in sample A could be attributed to the processing methods applied during the production of fermented millet flour (Ogi) [36] which may have resulted to the nutrient being leached, as bulk of the water used during the processing was discarded. The significant increase $(\mathrm{p}<0.05)$ in beta carotene content observed in MLF substituted samples with increased MLF is in agreement with the work of Shiriki et. al. [22] and Shar et. al. [37], The increased beta carotene content may be as a result of substitution effect, since moringa oleifera leaves has been reported to have high quantities of beta carotene [38]. The values obtained in this study is significantly $(\mathrm{p}<0.05)$ higher than the RDA of $1.5 \mathrm{mg} /$ day [24], and significantly $(\mathrm{p}<0.05)$ higher than $1.28 \mathrm{mg} / 100 \mathrm{~g}$ reported by GloverAmengor et al. [39].

Vitamin C content was in the range 0.58 to $3.89 \mathrm{mg} / 100 \mathrm{~g}$. The Vitamin C content of sample A may be as a result of fermentation as it has been reported that fermentation increases the vitamin $\mathrm{C}$ content of foods [40]. Vitamin C content also significantly $(\mathrm{p}<0.05)$ increased in MLF substituted samples with increased MLF leaf flour percentage. The higher vitamin C content of MLF substituted samples in this study with increased percentage might be attributed to their presence in the Moringa oleifera leaves
[33]. The values obtained in this study are significantly $(p<0.05)$ lower than the RDA of $20 \mathrm{mg} /$ day, sample $\mathrm{F}$ will provide up to $19.45 \%$ of the RDA [24]. This implies that other sources of vitamin $\mathrm{C}$ will be needed by the infants weaned using these blends in other to boost the vitamin C intake. Only a varied diet guarantees the supply of micronutrients, enhances good eating habits, and prevents the development of anorexia caused by monotonous foods [41], [42].

\section{Amino Acids}

The essential amino acids of the formulated weaning food samples substituted with moringa oleifera leaf flour (MLF) were significantly $(\mathrm{p}<0.05)$ higher than the control sample and compared favourably with the FAO/WHO reference values for weaning foods [43].

The essential amino acids methionine which is the limiting amino acids in legumes decreased significantly $(\mathrm{p}<0.05)$ with increased MLF substitution. Methionine contents of Samples $\mathrm{B}$ and $\mathrm{C}$ can provide 87.43 and $86.29 \%$ respectively, the FAO/WHO reference of 3.5 [43]. The observed decrease in methionine contents of the food formulations with increased MLF percentage maybe as a result of lower levels of methionine in Moringa oleifera leaves. This agrees with the findings of Bundit and Toshiro [44] that replacing moringa oleifera leaf partially by protein replacement in soya bean meal of fancy carp at increasing percentage decreased the methionine contents in the supplemented diets [44].

Tryptophan values increased significantly $(\mathrm{p}<0.05)$ in MLF substituted samples with increased MLF percentage. This may be attributed to the substitution effect of MLF. This is in agreement with the work of Shiriki et al. [22] who also reported an increased tryptophan content with increased MLF percentage.

Lysine contents were observed to decrease in MLF substituted samples with increased MLF substitution. Although, the formulated samples were still significantly $(p<0.05)$ higher than the control (sample A). The highest content of Lysine in sample B may be due to high percentage of soya beans in the formulation as soya beans is a highprotein legume and an excellent complement to lysine-limited cereal protein [45].

\section{Anti-Nutrients}

The phytate content in the range 0.19 to $0.21 \mathrm{mg} / 100 \mathrm{~g}$ significantly $(\mathrm{p}<0.05)$ decreased with increased MLF substitution. The observed decrease in phytate content with increased MLF percentage may be attributed to the low values of Phytate in MLF as reported by Kayi [38], and also may be attributed to the absence of seed coats as achieved by dehulling of the soya beans [46]. The phytate content observed to have decreased in this study is expected to enhance the bioavailability of proteins and dietary minerals such as iron, zinc, calcium and magnesium of the weaning food formulations [46]. Dietary phytate at low levels are said to have beneficial role as an antioxidant, anticarcinogens and are likely to play an important role in controlling hypercholesterolemia and atherosclerosis [47].

The oxalate content in the range 0.33 to $0.95 \mathrm{mg} / 100 \mathrm{~g}$ significantly $(\mathrm{p}<0.05)$ increased with increased MLF percentage. The concentration of oxalate found to be higher in MLF substituted samples may be as a result of large 
amounts of oxalate found in the stems and leaves of Moringa oleifera leaves [48]. This is similar to the findings of Ewolu et al. [49] who also reported increased oxalate content with increased MLF percentage in the production of kokoro. The oxalate content in this study is considered to be safe as they are below the safe normal range of $4-9 \mathrm{mg} / 100 \mathrm{~g}$ for oxalates as reported by Siddhuraju and Becker [50].

The Tannin content in the range 0.13 to $0.55 \mathrm{mg} / 100 \mathrm{~g}$ significantly $(\mathrm{p}<0.05)$ decreased with increased MLF substitution. The decreased tannin contents with increasing MLF percentage may be because tannin has been found negligible in all fractions of moringa oleifera plant [51]. This implies that Moringa leaves' tannins which is a proteininhibitor are not significant and may not affect the protein content of the formulated weaning foods when consumed [46].

Trypsin inhibitor found to be in the range 0.03 to $0.04 \mathrm{mg} / 100$ g. significantly $(\mathrm{p}<0.05)$ decreased with increased MLF substitution. The highest content of trypsin inhibitor found in (sample B) may be as a result of high percentage of soya beans in the formulations, as high levels of trypsin inhibitor is found in raw soya beans [52] but the low levels found in this study may be as a result of the processing methods used such as soaking, dehulling and degradation caused by heat treatment such as boiling and roasting applied in the processing of the soya beans flour [46].

The anti-nutrient levels were generally low and thus may not pose an immediate effect on the health of consumers. However, their presence suggests that a steady consumption may lead to toxic levels [52].

\section{CONCLUSION}

Processing technologies such as fermentation, dehulling, cooking, roasting and drying were applied to produce acceptable and improved nutrient quantity and quality micronutrient rich ready to use weaning food due to hydrolysis and degradation of complex food reserves to simpler absorbable molecules. The formulated weaning food particularly millet, soya bean and moringa oleifera leaf in the ratio 60:20:20 improved the micronutrient i. e. Minerals, Vitamins $\mathrm{A}$ and $\mathrm{C}$ and essential amino acids Tryptophan while sample B with millet and soya bean in the ratio 60:40 improved Lysine and Methionine. In some cases, even meeting the Recommended Daily Allowances (RDAs) for children $1-3$ year. The content of antinutrients also significantly $(\mathrm{p}<0.05)$ decreased but oxalate increased, although the levels were considered low and safe. The food formulations could therefore be used as weaning foods to improve micronutrients and boost food security especially in rural areas.

\section{ACKNOWLEDGMENT}

We acknowledge the management of the Centre for Food Technology and Research (cefter) headed by the centre leader Dr. Barnabas Ikyo, the project manager Dr. (Mrs) Igbun and deputy centre leader Dr. Sylvester Adejo for the sponsorship and commitment to the management of the centre.

\section{REFERENCES}

[1] U. Ismaila, A.S. Gana, N. M. Tswanya and D. Dogara D. Cereals Production in Nigeria: Problems Constraints and Opportunities for Betterment. African Journal of Agriculture, vol. 5, issue 12, pp. 13411350, June 2010.

[2] Y. Tehseen, Y. Ammara, N. Zahida, U. Shumaila, A. Sakhawat and S. P Anela shamshad. Development and Formulation of Ready to Eat Baby Food from Cereals. Journal of Food Sciences, vol 24 issue 3, pp. 121-125, 2014.

[3] F. Shahidi and A. Chandrasekara. Millets Grain Phenolics and their role in Disease Risk Reduction and Health Promotion: A review. Journal of Functional Foods, vol. 5, pp. 570-581, 2013.

[4] E. A Bonsi, W.A Plahar and R. Zabawa. Nutritional Enhancement of Ghanaian Weaning Foods using the Orange Flesh Sweet potato (Ipomea Batatas). African Journal of Food, Agriculture, Nutrition and Development, vol. 14, issue 5, pp. 2036-2056, August 2014.

[5] A. B Obilana and E. Manyasa. Millets. In: Pseudo Cereals and Less Common Cereals: Grain properties and Utilization Potential. PS Belton \& JRN Taylor (Eds.).Springer-Verlag: New York 2002, PP. 177-217.

[6] J. Henkel (2000)." Soy Health Claims for Soy Protein Question for Soy Protein. Question About Other Components". FDA Consumer (Food and Drug Administration) 34(3): 18-20 PMID 11521249.

[7] T. S. Anjorin, P. Ikokoh and S. Okolo and T. Anjorin. Mineral composition of Moringa oleifera leaves, pods and seeds from two regions in Abuja, Nigeria, International Journal of Agriculture and Biology, vol. 12, issue 3, pp. 431-434, 2010.

[8] S. M. Wakil, M. O. Kazeem. Quality assessment of Weaning Food Produced from Fermented Cereal-Legume Blends using Starters. International Food Research Journal, vol. 19, issue 4, pp. 1679-1685, March 2012.

[9] S. Villapando. Feeding Mode, Infections and Anthropometric Status in Early Childhood. Pediatrics, vol 106, issue 5, pp. 1282-1283 December 2000.

[10] WHO Global Strategy for Infant and Young Child Feeding. WH/A55/2002/REC/1 Annex 2, Geneva 2002.

[11] National population commission. Administrative unit: Benue State 2015.

[12] V. N. Enujiugha. Supplementation of Ogi, a Maize-Based Infant Weaning Food, with African Oil Bean (Pentaclethra macrophylla Benth). International Journal of Postharvest Technology and Innovation, vol. 1, no. 2, pp. 202-211, December 2006.

[13] S. Mariam. Nutritive Value of Three Potential Complementary Foods Based on Cereals and Legumes. African Journal of Food and Nutritional Sciences, vol. 5, no. 2, pp. 1-14, 2005.

[14] D. Shiriki, M.A. Igyor and D. I Gernah. Nutritional Evaluation of Complementary Food Formulations from Maize, Soybean and Peanut Fortified with Moringa oleifera Leaf Powder. Journal of Food and Nutrition Sciences, vol. 6 no. 5, pp. 494-500, January 2015.

[15] AOAC. Official Methods of Analysis, 18th edition. Association of Official; Analytical Chemists, Washington DC, 2012.

[16] R. R. Alexander, J. M. Griffiths. Basic Biochemical Methods 2, 2nd edition. John Willey and Sons Publications Inc. New York, 1993, pp. 353.

[17] I. Mohammed, A. Hassan and Y. Hazim. Determination of Vitamin C (Ascorbic Acid) Contents in Various Fruit and Vegetable by UVSpectrophotometry and Titration Methods. Journal of Chemical and Pharmaceutical Sciences; vol. 9, issue 4, pp. 2972-2974, Jamuary 2016.

[18] H. Kaspar, K. Dettmer and W. Gronwald Advances in amino acid analysis. Anal Bioanal Chem, vol. 393, pp. 445-452, 2009.

[19] P. S. Margit and M. P. Ibolya. Determination of Tryptophan in Unhydrolysed Food and Feedstuffs by Acid Ninhydrin Method Journal of Agricultural and Food Chemistry, vol. 38, pp. 720-726, 1990.

[20] G. I. Onwuka. Food Analysis and Instrumentation Theory and Practice. Naphthali Prints. Lagos, Nigeria 2005, pp. 114-119.

[21] M. Kakade, N. Simons and I. E. Liener. Determination of Trypsin Inhibitors Activity of Soybean Products. A Collaborative Analysis of an Improved Procedure. Cereal Chemistry, vol. 51, pp. 376-382, 1974.

[22] D. Shiriki, M. A. Igyor and D. I. Gernah. Effect of Moringa oleifera Leaf Powder Supplementation on the Micronutrient and Toxicant Contents of Maize - Soybean - Peanut Complementary Food Formulations. International Journal of Food Processing Technology, vol. 1, issue 2, pp.7-12, October 2014.

[23] V. F. Abioye and M. O. Aka. Proximate Composition and Sensory Properties of Moringa Fortified Maize-Ogi. Journal of Nutrition and Food Sciences vol. 12, issue 1, pp. 1-4, 2015. 
[24] SON. Standards of foods for infant and young children-infant formula. Standards Organization of Nigeria, Abuja. NIS, 2010; pp. 255-256.

[25] E. N. Whitney, E. M. N. Hamilton and S. R. Rolfes. Understanding Nutrition, 5th edn. New York: West Publishing Company, 1990.

[26] H. Richard and E. Ines. Iron Bioavailability and Dietary Reference Values. American Journal of Clinical Nutrition, vol. 91, issue 5, pp. 1461S-1467S, May 2010.

[27] N. Abbaspour, R, Hurrel and R. Kelishadi. Review on Irons and Its Importance for Human Health. Journal of Research in Medical Sciences, vol. 19, issue 2, pp. 164-174, 2014

[28] WHO. Facts for Feeding: Guidelines for Appropriate Complementary Feeding of Breastfed Children 6-24 Months of Age. Washington, 2004

[29] C. Parul and W. Keith W. Interactions between Zinc and Vitamin A. American Journal of Clinical Nutrition, vol. 68, issue 2, pp. 435-441, August 1998.

[30] A. Azhari, N. Mohammed, A. E. Mohamed and M. Ibrahim. Effect of Supplementation with Moringa Leaves Powder (MLP) and Fermentation on Chemical Composition, Total Minerals Contents and Sensory Characteristics of Sorghum Flour. International Journal of Science and Research, vol. 5, issue 3, pp. 672-677, March 2016.

[31] M. W. Gordon. Perspectives in Nutrition, 4th edition. Mc Graw Hill, N. Y, 1999, pp. 75-372.

[32] Institute of Medicine (IOM). Food and Nutrition Board. Dietary Reference Intakes: Calcium Phosphorus,Magnesium, Vitamin D and Flouride.Washington, DC: National Academy Press 1997.

[33] K. Netshiheni, M. Mashau and A. Jideani. Nutritional and Sensory Properties of Instant Maize Porridge Fortified with Moringa oleifera Leaves and Termite (Macrotermes falciger) Powders; Journal of Nutrition and Food Sciences, vol. 49, issue 4, pp. 654-667, July 2019

[34] M. Aslam, F. Anwar, R. Nadeem, U. Rashid, T. G. Kazi and M. Nadeem. Mineral Composition of Moringa oleifera Leaves and Pods from Different Regions of Punjab, Pakistan. Asian Journal of Plant Science, vol. 4, pp. 417-421, 2005.

[35] WHO. Feeding and Nutrition of Infants Young Children WHO Regional Publications, European series No 87, 2000.

[36] M. B. Reddy and M. Love. The Impact of Food Processing on the Nutritional Quality of Vitamins and Minerals. Advances in Experimental Medicine and Biology, vol. 45, pp. 99-106, 1999.

[37] F. M. Shar, B.D Igbabul, J. Ikya and N. Dabels. Quality Evaluation of Soy- mumu Supplemented with Moringa Leaf Powder. Journal of Food and Nutrition Sciences, vol. 4, issue 5, pp. 131-135, October 2016.

[38] K. K. Kayi. A Study on Moringa Oleifera Leaves as a Supplement to West African Weaning Foods. A Research Submitted to Hamburgh University of Applied Science 2013

[39] M. Glover-Amengor, A. Richmond, A. Edwin and N. Alexander. Micronutrient Composition and Acceptability of Moringa oleifera Leaf-Fortified Dishes by Children in Ada-East district, Ghana. Food Science and Nutrition, vol. 5, issue 2, pp. 317-323, July 2016.

[40] E. Egwin, M. Amanabo, A. Yahaya and M. Bello. Nigerian Indigenous Fermented Foods Processes and Prospects. Mycotoxins and Food Safety in Developing Countries, pp. 153-180, 2013.

[41] World Health Organization. Infant and Young Child Feeding: Model Chapter for Textbooks for Medical Students and Allied Health Professionals. Geneva: WHO Press, 2009.

[42] A. A .Motuma, L. Azeb, and G. Bekesho. Complementary Feeding: Review of Recommendations, Feeding Practices, and Adequacy of Homemade Complementary Food Preparations in Developing Countries - Lessons from Ethiopia. Frontiers in Nutrition, vol. 3, issue 41, 2016.

[43] D. I. Gernah, C. C. Ariahu and E. K. Ingbian. Nutritional and Sensory Evaluation of Food Formulations from Malted and Fermented Maize (Zea Mays L.) Fortified with Defatted Sesame (Sesamun Indicum L.) Flour. African Journal of Food, Agriculture, Nutrition and Development, vol. 12, no. 6, pp. 6614-6631, 2012.

[44] Y. Bundit and M. Toshiro. Replacing Moringa Partially by Protein Replacement in Soybean Meal of Fancy Carp (Cyprinus Carpio) Journal of Science and Technology, vol. 34, issue 5, pp. 479-485, September 2012.

[45] D. Chéreau, V. Pauline, R. Cécile, P. Lisa, M. Jean-Charles, B. Saliha, V. Jorge and L. Michel. Combination of Existing and Alternative Technologies to Promote Oilseeds and Pulses Proteins in Food Applications. EDP Sciences, vol. 23, issue 4, D406, 2016.

[46] S. O. Osunbitan, K. A. Taiwo and S. O. Gbadamosi. Effects of Different Processing Methods on the Antinutrient Contents in Two Improved Varieties of Cowpea. American Journal of Research Communication, vol. 3, issue 4, pp. 74-87, 2015.

[47] O. Omueti, B. Otegbayo, O. Jaiyeoba and O. Afolabi. Functional Properties of Complementary Diets Developed from Soybean
(Glycine Max), Groundnut (Macrobrachium SPP). Electronic Journal of Environmental, Agricultural and Food Chemistry; vol. 8, issue 8, pp. 563-573, 2016

[48] K. B. Dachana, R. D. Jyotsna and J. P. Indrani. Effect of Dried (Moringa Oleifera Lam) Leaves on Rheological, Microstructural, Nutritional, Textural and Organoleptic Characteristics of Cookies. Journal of Food Quality; vol. 3, issue 5, pp. 660-677, 2010.

[49] T. O Ewulo, I. B Oluwalana, B. S.Ewulo and O. O Awolu. (Enrichment of Traditional Maize Snack (Kokoro) with Moringa (Moringa Oliefera) Leaf and Soybean, African journal of food science, vol 11, issue 5, pp. 149-145, May 2017.

[50] P. Siddhuraju and K. Becker (2001). Effect of Various Domestic Processing Methods on Antinutrients and In Vitro Protein and Starch Digestibility of Two Indigenous Varieties of Indian Tribal Pulse, Mucuna Pruriens Var. Utilis. Journal of Agriculture and Food Chemistry, vol. 49, issue 6, pp. 58-67, June 2001.

[51] N. Reyes-Sanchez, E. Sporndly and I. Ledin. Effects of Feeding Different Levels of Foliage from Moringa Oleifera to Creole Dairy Cows on Intake, Digestibility, Milk Production and Composition. Livestock Science 101, issues 13, pp. 24-31, May 2006.

[52] J. RoosNanna, C. Sørensen, H. Sørensen, K. R. Søren, I. K. Zafar, A. Kafeel, Z. Asma, B. Humayan, H.Abrar, H Zile, A. S.Hazoor, Muhammad S, Ghulam H, Ijaz RN, Nudrat AA, Muhammad A, Fahim A, M. Irfan, T Vicenzo, F. Mariano and C. Eugenio. Assessment of Poisonous and Anti-Nutritional Compounds in Wild Edible Forages Consumed by Ruminant Species. Journal of Environmental Science and Technology, vol. 8, issue 3, pp. 91-101, March 2015

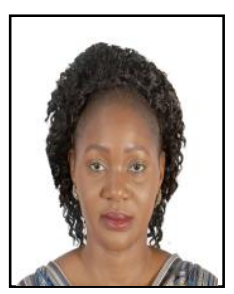

Jane Hembadoon Gwer was born in Gboko LGA of Benue state on the $30^{\text {th }}$ of April, 1986. Obtained Bachelor of Science degree in food technology, from the University of Agriculture Makurdi, Benue State in 2011. A Master of Technology in food science and technology from the Federal University of Technology Akure, Ondo State in 2015.

She is currently working as an ASSISTANT LECTURER in the department of Vocational and Technical Education at Benue State University Makurdi, Benue State. She has published articles such as "Nutritional and In vitro Glycemic Properties of Selected Indigenous Tubers", Asian Food Science Journal, 2018 " and Effect of substitution of soya beans and moringa oleifera leaf flour on the properties of a traditional weaning food", European Journal of Food Science and Technology, 2020". She does research in Food Nutrition and her current research is in Food processing and nutrition.

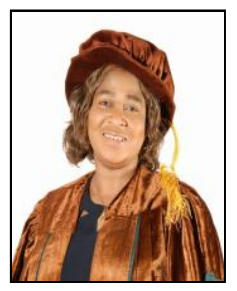

Prof. Mrs Bibiana Dooshima Igbabul was born in Vandeikya LGA of Benue state on the $15^{\text {th }}$ of May, 1969. Obtained Bachelor of Science and Master of Science degree in food science and technology, at the University of Agriculture Makurdi, Benue State in 1994 and 2001 respectively. A Doctor of Philosophy in food processing technology from the University of Agriculture Makurdi, Benue State in 2007.

She currently works as a professor in the

Department of Food Science and Technology, University of Agriculture, Makurdi, Benue State.

She has published articles such as "Proximate micronutrient composition, physical and sensory properties of cookies produced from wheat, sweet deter and moringa leaf flour blends. Current Research in Nutrition and food Science Journal, 2018. Quality Characteristics of Cookies Prepared from Wheat and Fermented Afzelia Africana. American Journal of Food Science and Technology, 2018. Physicochemical and Sensory Properties of Cookies Produced From Composite Flours of Wheat, Cocoyam and African Yam Beans, Journal of Food Research, 2015. She does research in food Processing and her current research is in Food processing and Food nutrition.

Prof. Igbabul is a member of Nigerian Institute of Food Science and Technology (NIFST) and Institute of Food Technologists, USA. 


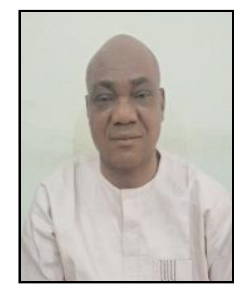

Prof. Simon Terver Ubwa was born in Mkar, Gboko LGA of Benue state on the $14^{\text {th }}$ September, 1966. Obtained Bachelor of Science chemistry, from the University of Calabar, Cross River State in 1991. Master of Science chemistry (organic chemistry) from the University of Ibadan in 1997.

A Doctor of Philosophy in pure and industrial chemistry (petroleum chemistry) from the University of Nigeria, Nsuuka, Enugu State in 2011.

He currently works as a professor in the Department of Chemistry, Benue State University, Makurdi. Simon does research in Food Chemistry, environmental organic chemistry and biofuels. His curren project is 'nutrition'. He has published articles such as Quantitative estimation of hydrogen Cyanide in fresh and cooked tuber Parenchyma (Pulp) of three Cultivars of sweet Cassava Cultivars grown in some parts of Benue State, Nigeria. Food and Nutriton Sciences, 2015. Effects of Traditional Smoking Methods on the concentration of Polynuclear aromatic Hydrocarbons (PAHs) in some species of Smoked Fish Traded in Benue State. Journal of Food Research. 2015. Assessment of Heavy metals in blood and some selected entrails of cows, Goats and Pigs slaughtered at Wurukum Abbatoir, Makurdi-Nigeria. Advanced Analytical Chemistry, 2017.

He does research in Food Chemistry, Environmental Organic Chemistry and Biofuels. His current project is 'nutrition'.

Prof Ubwa is member chemical Society of Nigeria (MCSN), Institute of chartered Chemist of Nigeria (MICCON). 